Vol4. No 1. Februari 2020

ISSN 2580-5029

\title{
Efektivitas Bokashi Daun Kelapa Sawit (Elaeisguineensis Jacq) Terhadap Produksi Kacang Kedelai (Glycine max (L.) Merr.) Di Pasaman Barat
}

\author{
Nursyahra ${ }^{*}$, Muhammad Rizki², Rizki ${ }^{3}$ \\ 1,2,3Program Studi Pendidikan Biologi STKIP PGRI Sumatera Barat, Indonesia \\ *muhammadrizki6900468@gmail.com
}

\begin{abstract}
The low production of soybeans in the West Pasaman district is due to severeal factors, including the lack of community knowledge in soybean farming which results in less productive yields obtained by farmer and the high use of inorganic fertilizers continuously resulting in less productive soil. This study was experimental research using a completely randomized design (CRD). The treatments given were 6 treatments and 5 replications, the treatments used were 15 gram TSP (A treatment) as control treatments, 300 gram bokashi (B treatment), 400 gram bokashi ( $C$ treatment), 500 gram bokashi ( $D$ treatment), 600 gram bokashi ( $E$ treatment), 700 gram bokashi ( $F$ treatment). The data obtained were analyzed by analysis of variance and then continued by LSD test at a level of 5\%. Observed parameters were the number of planting seeds and weight of 50 seeds per plant. The results of this study indicated that bokashi fertilizer had no significant effect on the number of seeds but it had significant effect on the weight of 50 seeds and the best result was found in $B$ treatment (300 gram bokashi/polybag). This research had environmental conditions with temperatures of $30-34^{\circ} \mathrm{C}$, environmental humidity of $63-80 \%$, wind speeds of 0,2 to $2,8 \mathrm{~m} / \mathrm{s}$, and soil $p H$ of 5,4 to 7,0 .
\end{abstract}

Keywords: Soy, Effectiveness, Palm Bokashi Fertilizer.

\section{ABSTRAK}

Rendahnya produksi kacang kedelai di kabupaten Pasaman Barat disebabkan beberapa hal, diantaranya kurangnya pengetahuan masyarakat dalam bertani kacang kedelai, penyebab lain rendahnya produksi kedelai adalah tingginya pemakain pupuk anorganik mengakibatkan tanah kurang produktif. Penelitian ini adalah eksperimen dengan menggunakan Rancangan Acak Lengkap (RAL). Perlakuan yang diberikan 6 perlakuan dan 5 ulangan, perlakuan yang digunakan ialah perlakuan A 15 gram TSP (kontrol), Perlakuan B 300 gram bokashi, perlakuan C 400 gram bokashi, perlakuan D 500 gram bokashi, perlakuan E 600 gram bokashi, perlakuan F 700 gram bokashi. Data yang diperoleh dianalisis dengan analisis ragam kemudian dilakukan uji lanjut uji BNT pada taraf $\alpha 5 \%$. Parameter pengamatan meliputi jumlah biji pertanaman dan berat 50 biji pertanaman. Hasil penelitian ini menunjukkan pada jumlah biji pertanaman pemberian pupuk bokashi daun kelapa sawit berpengaruh tidak nyata, sedangkan untuk parameter berat 50 biji pertanaman berpengaruh nyata dan perlakuan B (300 gram bokashi/polybag) merupakan hasil terbaik, sedangkan kondisi lingkungan penelitian memiliki suhu lingkungan $30-34^{\circ} \mathrm{C}$, kelembapan lingkungan $63-80 \%$, kecepatan angin $0,2-2,8 \mathrm{~m} / \mathrm{s}$, dan pH tanah 5,4-7,0.

Kata Kunci: Kedelai, Efektivitas, Pupuk Bokashi Sawit 


\section{PENDAHULUAN}

Kedelai (Glycine max (L.) Merr.)adalah tanaman pangan, yang digunakan sebagai sumber protein nabati. Kebutuhan kedelai dalam negeri terus meningkat, namun meningkatnya kebutuhan kedelai tidak sebanding dengan produktivitasnya. Penyebab kurangnya produktivitas kedelai adalah luas panen yang tidak memadai dikarenakan bertambahnya jumlahpenduduk, sehingga lahan pertanian beralih fungsimen jadi daerah pemukiman (Milani, Rosmayati, \& A., 2013).

Berdasarkan hasil observasi yang telah dilakukan di Kabupaten Pasaman Barat usaha masyarakat berupa perkebunan kelapa sawit dan pohon karet, sedangkan bagian pertanian berupa jagung, padi dan tanaman lainnya seperti kacang kedelai (Glycine $\max$ (L.) Merr.). Dilihat Dari data Dinas Tanaman Pangan Hortikultura dan Peternakan (DTPPHP) KabupatenPasaman Barat, 2017) pertanian kacang kedelai dari tahun ke tahun mengalami penurunan, hal itu dilihat dari empat bagiannya itu dari luas area tanam, luas area panen, produksi, dan produktivitas kedelai. Padaluas area tanamant ahun 2012: 310 ha, 2013: 315 ha, 2014: 319 ha, 2015: 35 ha, 2016: 14 ha, 2017:16 ha, padal uas area panen tahun 2012:300 ha, 2013: 244 ha, 2014: 357 ha, 2015:97 ha, 2016:20 ha, 2017:14 ha, pada produksi (ton) tahun 2012: 350 ton, 2013: 209 ton, 2014: 371 ton, 2015: 132 ton, 2016: 23 ton. Pada produktivitas (ton/ha) tahun 2012: 1,17 ton/ha, 2013: 0,86 ton/ha, 2014: 1,04 ton/ha, 2015: 1,36 ton/ha, 2016: 1,15 ton/ha, 2017:1 ton/ha

Rendahnya produksi kacang kedelai di kabupaten Pasaman Barat disebabkan oleh beberapa hal, diantaranya ialah kurangnya pengetahuan masyarakat dalam bertani kacang kedelai yang mengakibatkan kurang produktifnya hasil yang didapatkan oleh petani dan beralih ke tanaman lain. Penyebab lain rendahnya produksi kedelai adalah tingginya penggunaan pupuk anorganik secara terus menerus mengakibatkan tanah kurang produktif, hal ini dilihat dari data Status Lingkungan Hidup Daerah (SLHD) Sumatera Barat bahwa penggunaan pupuk anorganik di Provinsi Sumatera Barat tertinggi adalah kabupaten Pasaman barat, yaitu dengan angka penggunaan $6.727,25$ ton (Widia et al., 2015).

Penyebab lain dari rendahnya produksi kedelai adalah pengalihan fungsi lahan pertanian menjadi lahan perkebunan hal itu bisa dilihat dari data RKPD Pasaman Barat tahun 2018, yaitu pengalihan lahan menjadi perkebunan dalam waktu 5 tahun terakhir mengalam peningkatan yang cukup pesat, padatahun 2011, lahan perkebunan di kabupaten Pasaman Barat mencapai 146.469 ha dan pada tahun 2015 mengalami peningkatan yaitu mencapai 161.522 ha atau 41,55\% dari luas wilayah kabupatenPasaman Barat (Bupati, 2017). Dilihat dari tingginya penggunaan pupuk anorganik oleh petani mengakibatkan rusaknya substrat tanah yang mengakibatkan tanah menjadi tidak subur, 
sehingga perlu dilakukan pengalihan ataupun mengimbangi penggunaan pupuk anorganik dengan menggunakan pupuk alami atau organik yang bisa mengembalikan kesuburan tanah yang sudah rusak substratnya. Fungsi pupuk organik ialah meningkatkan kesuburan tanah, karena pupuk organik bisa menggemburkan bagian lapis atas tanah (top soil), menambah jasad renik, mempertinggi daya simpan air dan daya serap air.

Oleh karena itu penulis telah melaksanakan penelitian tentang "Pemberian Bokashi Daun Kelapa Sawit Terhadap Produksi Kacang Kedelai (Glycine Max (L.)Merr.) di Pasaman Barat.". Tujuan penelitian ini adalah untuk melihat produksi kacang kedelai dengan pemberian pupuk bokashi daun kelapa sawit yang dilihat pada bagian jumlah biji per polong dan berat 50 biji (gram) pertanaman dan untuk mengetahui kondisi lingkungan yang meliputi suhu, pH tanah, kelembaban dankecepatan angin di daerah penelitian.

\section{METODE}

Penelitian telah dilaksanakan pada bulan Januari 2019 - April 2019 di Nagari Persiapan Anam Koto Selatan, Kecamatan Kinali, Kabupaten Pasaman Barat

Adapun alat yang digunakan pada penelitian ini adalah meteran, alat pemotong, kertas label, polybag ukuran $10 \mathrm{~kg}$, terpal, pisau, plastik, cangkul, Neraca Ohause, alat tulis, ember, $\mathrm{pH}$ tanah, termhometer, animo meter. Bahan yang digunakan ialah bokashi daun kelapa sawit, pupuk TSP, benih kedelai DEGA 1, tanah, dan fungisida. Bokashi daun kelapa dibuat sendiri dengan cara daun kelapa sawit dipotong-potong dengan ukuran 6-10 $\mathrm{cm}$ seberat $50 \mathrm{~kg}$, setelah daun dipotong-potong lalu dibuat cetakan dengan ukuran $100 \mathrm{~cm}$ x $75 \mathrm{~cm}$, lalu daun kelapa sawit dimasukkan kedalam cetakan dengan ketebalan $15 \mathrm{~cm}$ dan kotoran puyuh dan pupuk TSP ditaburkan di atas tumpukan daun sawit secara merata, lalu siramkan aktivator EM4 secara merata, lalu tambahkan lagi lapisan kedua sampai lapisan ke empat sesuai prosedur yang dilakukan pada lapisan pertama, setelah lapisan ke empat selesai, tumpukan daun kelapa sawit di tutup rapat menggunakan plastik hitam hingga tidak ada lagi celah udara yang masuk. Setelah 1 minggu dilakukan pengadukan bokhasi, apabila bokhasi dalam keadaan panas maka dibiarkan sementara untuk pendinginan bokhasi, apabila bokashi dalam keadaan kering maka dilakukan penyiraman pada bokhasi secara merata. Kematangan bokhasi kurang lebih selama 1 bulan.

Penelitian ini merupakan penelitian eksperimen dengan menggunakan Rancangan Acak Lengkap (RAL), dengan 6 perlakuandan 5 ulangan, yaitu: A: 15 gram/tanaman (TSP), B: 300 gram/tanaman (Bokashi), C: 400 gram/tanaman (Bokashi), D: 500 gram/tanaman (Bokashi) (Arifin, Nisa, \& Titin, 2018), E: 600 gram/tanaman (Bokashi) dan F: 700 gram/tanaman (Bokashi).

Adapun parameter yang diukur pada 
pada penelitian ini adalah Jumlah polong per tanaman, Jumlah Biji Pertanaman, Berat biji pertanaman. Sedangkan data pada penghitungan jumlah polong, jumlah biji per polong berat kering 50 biji (gram) digunakan analisis ragam uji f pada taraf $\alpha 5 \%$ jika $\mathrm{f}$ hitung lebih besar dari $\mathrm{f}$ tabel maka dilakukan uji lanjut dengan uji BNT (Suin, 2001).

\section{HASIL DAN PEMBAHASAN}

Berdasarkan dari penelitian yang telah dilakukan tentang efektivitas bokashi daun kelapa sawit terhadap kacang kedelai (Glycine max (L.) Merr.) di Pasaman Barat didapatkan hasil sebagaimana tabel 1 .

Dari analisis sidik ragam dan uji lanjut pada taraf $\alpha$ 5\% diketahui penggunaan bokashi daun kelapa sawit untuk jumlah biji pertanaman berpengaruh tidak nyata, sedangkan 50 biji/tanaman bokashi berpengaruh nyata, sehingga dilakukan uji lanjut BNT, setelah dilakukan uji lanjut perlakuan B, C, D, E, F berbeda nyata terhadap perlakuan A.

Tabel 1. Analisis Sidik Ragam, Hasil Uji Lanjut dan Notasi Jumlah Biji Pertanaman dan Berat 50 Biji Pertanaman (Glycine max (L.) Merr.)

\begin{tabular}{lcc}
\hline Perlakuan & $\begin{array}{c}\text { Jumlah Biji } \\
\text { pertanaman }\end{array}$ & Berat $\mathbf{5 0 ~ b i j i ~ P e r t a n a m a n ~ ( g r a m ) ~}$ \\
\hline $\mathrm{A}($ Kontrol $)$ & 98,2 & $8,94 \mathrm{~b}$ \\
$\mathrm{~B}(300 \mathrm{~g})$ & 106,8 & $11,6 \mathrm{a}$ \\
$\mathrm{C}(400 \mathrm{~g})$ & 102,2 & $10,9 \mathrm{a}$ \\
$\mathrm{D}(500 \mathrm{~g})$ & 97,2 & $10,52 \mathrm{a}$ \\
$\mathrm{E}(600 \mathrm{~g})$ & 90,2 & $10,62 \mathrm{a}$ \\
$\mathrm{F}(700 \mathrm{~g})$ & 103,6 & $10,28 \mathrm{a}$ \\
\hline
\end{tabular}

Keterangan: Parameter jumlah biji pertanaman berpengaruh tidak nyata pada uji taraf $\alpha 5 \%$, sehingga tidak dilakukan uji lanjut, sedangkan parameter berat 50 biji pertanaman berpengaruh nyata dan dilakukan uji lanjut BNT taraf $\alpha 5 \%$, perlakuan yang diikuti huruf yang sama, maka tidak berbeda nyata pada taraf $\alpha 5 \%$, sedangkan perlakuan yang tidak diikuti huruf yang sama maka berbeda nyata pada taraf $\alpha 5 \%$.

Hasil uji BNT yang didapatkan bahwa pemberian bokashi daun kelapa sawit berpengaruh tidak nyata (tidak ada perlakuan yang pengaruhnya menonjol dibandingkan kontrol) terhadap parameter jumlah biji pertanaman, namun jika dilihat dari hasil tertinggi terdapat pada perlakuan

$300 \mathrm{~g} /$ tanaman, hal ini diduga dengan jumlah 300g/tanaman bokashi sudah mencukupi kebutuhan hara tanaman dan memiliki konsentrasi optimal, dan tidak membuat tanah menjadi terlalu masam.

Menurut Zahrah (2011) dalam melakukan pemupukan lebih baik jika menggunakan jenis, pupuk, dosis, cara dan waktu yang tepat. kekurangan atau kelebihan unsur hara termasuk $\mathrm{N}, \mathrm{P}$ dan $\mathrm{K}$ akan berpengaruh terhadap pertumbuhan dan produksi".

Bokashi daun kelapa sawit juga dapat meningkatkan kinerja mikroorganisme tanah 
yang terkandung dalam bokashi yang bisa membantu proses perombakan bahan organik, sehingga menaikkan penyerapan unsur hara yang dibutuhkan oleh tanaman.Saro (2007) menyatakan kemampuan tanaman terhadap asupan unsur hara ditentukan oleh kemampuan akar untuk menyerap unsur hara dan tinggi rendahnya mikroorganisme tanah dalam metabolisme senyawa organik, makin banyak akar dan nutrisi yang terbentuk dalam tanah maka produksi bunga dan polong dari tanaman makin baik pula dan kemampuan untuk menghasilkan biji yang baik makin tinggi.

Operasisco, dkk., (2012) mengemukakan bahwa pemberiaan pupuk bokashi dapat meningkatkan produksi tanaman. Menurut (Rohman \& Eriani, 2001) Proses dekomposisi bahan organik tanah dipengaruhi oleh mikroorganisme tanah, yang bisa meningkatkan tersedianya zat hara N, P, dan K sehingga dengan ketersedianya unsur hara, bisa menaikkan pertumbuhan dan hasil tanaman.

Pada berat 50 biji, setelah dilakukan uji lanjut BNT didapatkan hasil perlakuan B, C, D, E, F notasinya berbeda dengan perlakuan A, hal ini kemungkinan terjadi diakibatkan oleh ketersediaan hara tanaman dalam pembentukan unsur $\mathrm{P}$ lebih baik dibandingkan ketersediaan unsur $\mathrm{P}$ dalam kontrol. Menurut Arifin et al., (2018) semakin banyak unsur P yang disediakan dan diserap oleh tanaman maka bobot biji kedelai semakin naik. Menurut Siregar \& Annisa (2016) bahwa pupuk P merupakan salah satu pupuk yang diperlukan dalam pertumbuhan awal tanaman sebagai pembentukan lemak yang akan menghasilkan biji dan mempercepat matangnya polong. .

Berdasarkan pengukuran pada faktor lingkungan, didapatkan data sebagaimana pada tabel 2. Secara garis besar faktor lingkungan yang didapatkan dilapangan tersebut telah sesuai dengan kriteria iklim pertumbuhan bagi kedelai.

Tabel 2.Faktor Lingkungan Lokasi Penelitian

\begin{tabular}{llc}
\hline No & $\begin{array}{l}\text { Faktor } \\
\text { Lingkungan }\end{array}$ & Satuan \\
\hline 1 & Kelembaban & $63-80 \%$ \\
2 & Suhu & $30-34{ }^{\circ} \mathrm{C}$ \\
3 & kecepatanAngin & $0,2-2,8 \mathrm{~m} / \mathrm{s}$ \\
4 & pH Tanah & $5,4-7,0$ \\
\hline
\end{tabular}

Menurut Adisarwanto

(2008)

kelembaban udara optimal berkisar 75-90\% sedangkan yang didapatkan yaitu 63-80 \%, maka kelembaban udara sudah sesuai dengan kelembaban optimal pertumbuhan tanaman kedelai. Pada tingkat keasaman tanah menurut Atman (2014) memilki toleransi sedikit masam sampai netral $(5,5-7,0)$ hal ini sesuai dengan hasil yang didapatkan dilapangan $\mathrm{pH}$ tanah 5,4-7,0. Pada kecepatan angin didapatkan hasilnya $0,2-2,8 \mathrm{~m} / \mathrm{s}$, pada kecepatan angin sangat mempengaruhi terhadap proses pembungaan, apabila kecepatan angin sangat tinggi maka bunga kedelai bisa gugur dan mengurangi pembentukan polong kedelai.

Sedangkan pada suhu lingkungan yang didapatkan yaitu berkisar optimal yaitu 30$34^{\circ} \mathrm{C}$, Hal ini kurang sesuai dengan suhu 
optimal tumbuh kedelai dimana suhu optimal dari kedelai adalah $25-36^{\circ} \mathrm{C}$, apabila suhu tinggi $30-36^{0} \mathrm{C}$ maka tanaman tumbuh pendek, cepat berbunga bila air kurang tanaman merana dan suhu lingkungan optimal pada proses pembungaan bunga yaitu $24-25^{\circ} \mathrm{C}$ sedangkan yang didapatkan dilapangan berkisar antara $30-34^{\circ} \mathrm{C}$, hasil ini melihatkan bahwa tingkat suhu lebih tinggi dari suhu optimal dan dapat mengakibatkan bunga pada kedelai mudah rontok sehingga buah kedelai berkurang.

Hasil yang didapatkan ini maka pupuk bokashi daun kelapa sawit bisa digunakan sebagai pengganti pupuk anorganik yang biasa digunakan oleh petani, hal ini sama dengan hasil yang didapatkan pada riset ini dilihat pada berat 50 biji pertanaman didapatkan hasilnya tiap perlakuan bokashi tidak berbeda nyata, namun perlakuan 300 gram/tanaman dengan hasil rata-rata 11,6 gram/tanaman $\quad(1,856$ ton/hektare $)$ merupakan perlakuan paling rendah dan bisa mengoptimalkan biaya pengeluaran petani. Mengingat juga bahwa dengan menggunakan bokashi daun kelapa sawit bisa mengembalikan kesuburan tanah yang sudah rusak.

\section{KESIMPULAN}

Dari penelitian yang telah dilakukan dapat disimpulkan bahwa Pemberian pupuk bokashi daun kelapa sawit berpengaruh tidak nyata pada jumlah biji pertanaman, sedangkan berat 50 biji pertanaman berpengaruh nyata. Dari parameter yang ada hasil terbaik didapatkan pada perlakuan B (300 gram bokashi/polybag) dan kondisi lingkungan penelitian sudah sesuai untuk tanaman kedelai.

\section{DAFTAR PUSTAKA}

Adisarwanto. (2008). Budidaya Kedelai Tropika. Jakarta: Penebar Swadaya.

Arifin, M., Nisa, C., \& Titin, Z. M. (2018). Respon Pertumbuhan dan Hasil Kedelai Varietas Anjasmoro Terhadap Pemberian Bokashi Serabut Buah Kelapa Sawit.JTAM Agroekotek View, 1(1), 13-20.

Atman. (2014). Strategi Meningkatkan Produksi Kedelai Melalui PTT. Yogyakarta: Graha Ilmu.

Bupati. (2017). Peraturan Bupati Pasaman Barat Tentang Rencana Kerja Pemerintah daerah tahun 2018. Pasaman Barat: Pemerintah Kabupaten Pasaman Barat.

Dinas Tanaman Pangan Hortikultura dan Peternakan (DTPPHP) Kabupaten Pasaman Barat. (2017).

Milani, A., Rosmayati, \& A., L. M. S. (2013). Pertumbuhan dan Produksi Beberapa Varetas Kedelai Terhadap Inokulasi Bradyrhizobium.Jurnal Online Agroekoteknologi, 1(2), 16-23.

Operasisco, Y. G., Aziz, L. M. S., \& Husni, Y. (2012). Respon Pertumbuhan dan Produksi Beberapa Varietas Kedelai (Glycine max (L.) Merrill) Terhadap Pemberian Pupuk Bokashi.Jurnal Online Agroekoteknologi, 1(1), 220-236.

Saro, D. (2007). Mutu Produksi Biji Tanaman Kedelai (Glycine max L.) Dengan Pemberian Bokashi serta Penyiraman Turunan EM-4. Agroland,14(September), 208-210. 
Siregar, \& Annisa, D. (2016). Respon Pertumbuhan dan Produksi Kedeleai (Glycine $\max$ (L.) Merril.) Terhadap Pemberian Biochar Sekam Padi dan Pupuk P.Skripsi Sarjana Universitas Sumatera Barat.

Suin, N. M. (2001). Biostatistik. Padang: Yayasan Perguruan Tinggi Komputer Padang.

Widia, D. K., Dasril, Zami, V., Adrian, Rina, R. A., Desrizal,Harian, D. (2015). Status Lingkungan Hidup Daerah Provinsi Sumatera Barat (Nasaruddin, Yantonius, S. Aisyah, Novarita, \& Petriawaty, Eds.). Sumaera Barat: Bapedalda Provinsi Sumatera Barat.

Zahrah. (2011). Respon Berbagai Kedelai (Glycine $\max$ (L.) Merril) Terhadap Pemberian Pupuk NPK Organik.Jurnal Teknologi, 2(1), 65-69. 